\title{
Decolorization of textile industry wastewater in solid state fermentation with Peach-Palm (Bactris gasipaes) residue
}

\author{
J. A. Chicatto ${ }^{a}$, K. T. Rainert ${ }^{a}$, M. J. Gonçalves ${ }^{b}$, C. V. Helm ${ }^{c}$, D. Altmajer-Vaz ${ }^{d}$ \\ and L. B. B. Tavares ${ }^{a}$ \\ ${ }^{a}$ Environmental Engineering Postgraduate, Universidade Regional de Blumenau - FURB, \\ Rua São Paulo, no 3250, Itoupava Seca, CEP 89030-080, Blumenau, SC, Brazil \\ ${ }^{\text {b}}$ Department of Chemical Engineering, Universidade Regional de Blumenau - FURB, \\ Rua São Paulo, n 3250, Itoupava Seca, CEP 89030-080, Blumenau, SC, Brazil \\ 'National Research Center for Forestry, Embrapa Florestas, Estrada da Ribeira, Km 111, \\ CEP 83411-000, Colombo, PR, Brazil \\ ${ }^{\mathrm{d}}$ Department of Chemical Engineering, Universidad de Granada - UGR, \\ Avenida del Hospicio, s/n, 18010, Granada, España \\ *e-mail: julianech@correo.ugr.es
}

Received: January 30, 2017 - Accepted: June 29, 2017 - Distributed: November 30, 2018

(With 2 Figures)

\begin{abstract}
In this work we have assessed the decolorization of textile effluents throughout their treatment in a solid-state fermentation (SSF) system. SSF assays were conducted with peach-palm (Bactris gasipaes) residue using the white rot fungus Ganoderma lucidum EF 31. The influence of the dye concentration and of the amounts of peach-palm residue and liquid phase on both the discoloration efficiency and enzyme production was studied. According to our results, independently of experimental conditions employed, laccase was the main ligninolytic enzyme produced by G. lucidum. The highest laccase activity was obtained at very low effluent concentrations, suggesting the existence of an inhibitory effect of higher concentrations on fungal metabolism. The highest percentage of color removal was reached when 10 grams of peach palm residue was moistened with $60 \mathrm{~mL}$ of the final effluent. In control tests carried out with the synthetic dye Remazol Brilliant Blue R (RBBR) decolorization efficiencies about 20\% higher than that achieved with the industrial effluent were achieved. The adsorption of RBBR on peach-palm residue was also investigated. Equilibrium tests showed that the adsorption of this dye followed both Langmuir and Freundlich isotherms. Hence, our experimental results indicate that peach-palm residue is suitable substrate for both laccase production and color removal in industrial effluents.
\end{abstract}

Keywords: dye, solid-state fermentation, Ganoderma lucidum, oxidative enzymes.

\section{Decoloração de águas residuais da indústria têxtil em fermentação de estado sólido com resíduo de Pupunha (Bactris gasipaes)}

\begin{abstract}
Resumo
Neste trabalho, avaliamos a descoloração de efluentes têxteis durante seu tratamento em um sistema de fermentação em estado sólido (SSF). Os ensaios foram conduzidos com resíduo de pupunha (Bactris gasipaes) utilizando o fungo de podridão branca Ganoderma lucidum EF 31. A influência da concentração de corante, as quantidades de resíduo e da fase líquida foram estudadas tanto na eficiência de descoloração como na produção de enzima. De acordo com os resultados, independentemente das condições experimentais utilizadas, a lacase foi a principal enzima ligninolítica produzida por G. lucidum. A atividade de lacase mais elevada foi obtida em baixas concentrações de efluentes, sugerindo um efeito inibitório no metabolismo fúngico. A maior remoção de cor foi obtida com 10 gramas de resíduo da pupunha e $60 \mathrm{~mL}$ do efluente final. Nos ensaios de controle realizados com o corante sintético RBBR, foram atingidos cerca de $20 \%$ mais descoloração do que os obtidos com o efluente industrial. A adsorção de RBBR no resíduo de pupunha também foi investigada. Os testes de equilíbrio mostraram que a adsorção deste corante seguiu as isotermas de Langmuir e Freundlich. Assim, os resultados experimentais indicam que o resíduo de pupunha é um substrato adequado tanto para a produção de lacase quanto para a remoção de cor em efluentes industriais.
\end{abstract}

Palavras-chave: corante, fermentação em estado sólido, Ganoderma lucidum, enzimas oxidativas. 


\section{Introduction}

The peach palm (Bactris gasipaes Kunth) is widespread in Brazil and is one of the major producers of the heart-of-palm (locally known as "palmito") (Helm et al., 2014) with a harvested area of 22, 537 ha and a production of 10,940 tons in 2015 (IBGE, 2015). The residue (leaf sheath) of the stem generated by the industry during the processing of canned heart-of-palm corresponds to about $85-95 \%$ of the weight of the palm depending on the species, and currently has no economic value, and important environmental impact (Helm et al., 2014). However, palm tree residues have potential as a solid-matrix support for solid state fermentation using microorganisms (Abulnaja and Abou-Zeid, 1993), and may also have potential to act as a sorbent of dyes in textile wastewater (Guiza et al., 2014) due to porosity and the presence of chemical groups that enable hydrolytic action of enzymes in cultivated fungus.

Textile industry wastewater is composed of a vast array of complex components, including synthetic dyes, dispersants, bases, acids, detergents, salts, surfactants, grease, and oil, among other compounds (Pelosi et al., 2014). The environmental problems associated with these effluents are mainly attributed to two factors: (i) the large volumes of wastewater generated in the textile industry and, (ii) the stable and recalcitrant nature of the dyes (Srinivasan and Viraraghavan, 2010). Anthraquinone-based dyes, e.g., Remazol Brilliant Blue R (RBBR), constitute the second largest class after the azo dyes (Gregory, 1990) and are considered the most resistant to degradation (Jaouani et al., 2003).

White rot fungi (WRF) are well known for their ability to degrade lignin and a wide range of xenobiotic pollutants that accumulate in soil and water, including dyes, polycyclic aromatic hydrocarbons, polychlorinated biphenyls, explosives, and pesticides (Asgher et al., 2012). The enzymatic system of WRF consists of laccase enzymatic (EC 1.10.3.2), lignin peroxidases (EC 1.11.10.14) and manganese peroxidases (EC 1.11.1.13) (Liers et al., 2013), which allow cleavage of the aromatic rings in dyes. The synthesis and secretion of these enzymes is influenced by nutrient levels, culture conditions, and fungal developmental stage, as well as by the addition of inducers to culture media (Piscitelli et al., 2011; Rao et al., 2014).

Ganoderma lucidum is one of the most widely distributed WRF in the world. Several studies of G. lucidum focus on its laccase-producing capacity and its ability for the degradation of dyes and organic compounds (Rivera-Hoyos et al., 2015; Kuhar et al., 2015; Zhou et al., 2012).

Despite these studies, the potential of G. lucidum and its ligninolytic enzymes in bioremediation processes is still far from being fully explored. Until now, most studies on dye discoloration with G. lucidum have been carried out using submerged liquid fermentation (Zhou et al., 2015; Sadaf et al., 2013) a system which does not reproduce the natural living conditions of the WRF. Other studies, particularly those focused on the production of fungal enzymes, have successfully employed solid-state fermentation (SSF) (El Batal et al., 2015; Yao et al., 2013; Selvakumar et al., 2013). The two main advantages of SSF compared to submerge fermentation are the higher yields attained and the possibility of reusing solid wastes from agriculture and food processing (Selvakumar et al., 2013).

In this work we study de discoloration of an industrial textile wastewater in a SSF system, in which two processes are carried out concomitantly: (i) the biodegradation of the dyes by the WRF, G. lucidum, and (ii) the adsorption of the dyes by a solid matrix comprised by the peach palm residue. With that purpose, the adsorption capacity of palm tree residue was firstly evaluated using Remazol Brilliant Blue R as a model dye. After that, SSF assays were conducted with different amounts of peach palm residue, liquid phase, and dye concentrations. In SSF assays, the peach palm residue acts as support and "nutrient source" for cultivation of G. lucidum, which can grow on the surface of palm sheaths thanks to its lignin content.

\section{Materials and Methods}

\subsection{Fungal strains and culture conditions}

The white-rot fungi G. lucidum EF31 was kindly provided by the National Research Center for Forestry (EMBRAPA/Colombo, PR, Brazil). The isolate was cultivated in Petri dishes containing potato dextrose agar (PDA) medium, in the dark for seven to ten days at $25 \pm 1{ }^{\circ} \mathrm{C}$. Afterwards, cultures were stored at $4{ }^{\circ} \mathrm{C}$ and maintained for a maximum of 2 weeks.

\subsection{Dye solution and industrial wastewater}

The decolorization process was carried out with RBBR solutions (Sigma-Aldrich) and two different dye wastewaters: (i) Residual dyebath effluent (RDB), which is the wastewater produced during the washing process of dyed material; and (ii) the final effluent (FE), collected at the end of the primary physiochemical treatment and prior to biological treatment. Both wastewaters were provided from a textile industry that processes cellulose textile fibers located in Santa Catarina, Brazil.

\subsection{Peach palm residue}

The peach palm sheath (Bactris gasipaes) used in this work is an agro-industrial waste generated from palm tree extraction. It was kindly provided by an agribusiness company in Santa Catarina, Brazil. The residue (leaf sheath) was milled in a knife mill into $2 \mathrm{~mm}$ particles and dried at $60{ }^{\circ} \mathrm{C}$ for 24 hours prior to use. Both wastewaters were used without prior treatment.

\subsection{Adsorption kinetics and equilibrium adsorption isotherm}

Kinetic studies of RBBR adsorption on peach palm residue were performed in $250 \mathrm{ml}$ Erlenmeyer flasks containing $100 \mathrm{~mL}$ of dye solution $\left(50 \mathrm{mg} . \mathrm{L}^{-1}\right)$ and $2.0 \mathrm{~g}$ of adsorbent. The mixture was stirred in a shaker (Tecnal TE-421) for $48 \mathrm{~h}$ at $28^{\circ} \mathrm{C}$ at a constant speed of $50 \mathrm{rpm}$ (solution pH: 6.20). Each vial was removed from the shaker at predetermined time intervals and then the samples were 
immediately filtered using a vacuum pump filter. The dye concentration of each sample was determined by reading the absorbance in a spectrophotometer (Shimadzu UV-1650) at $590 \mathrm{~nm}$. The quantity of adsorbate adsorbed in time t, $\mathrm{q}_{\mathrm{t}}\left(\mathrm{mg} \cdot \mathrm{g}^{-1}\right)$ was calculated using Equation (1).

$q_{t}=\frac{\left(C_{0}-C_{e}\right) * V}{m}$

where $\mathrm{q}_{\mathrm{t}}$ is the adsorbate concentration at time $\mathrm{t}$ adsorbed by the adsorbent $\left(\mathrm{mg} \cdot \mathrm{g}^{-1}\right)$ at equilibrium conditions, $\mathrm{C}_{\mathrm{o}}$ is the initial concentration of the compound (mg. $\left.\mathrm{L}^{-1}\right), \mathrm{C}_{\mathrm{e}}$ is the equilibrium concentration in solution $\left(\mathrm{mg} . \mathrm{L}^{-1}\right), \mathrm{m}$ is the mass of adsorbent $(\mathrm{g})$, and $\mathrm{V}$ is the solution volume (L). The dye-adsorbed amounts obtained throughout the experiments were used to fit pseudo-first order and pseudo-second order models, as well as intraparticle diffusion model.

Adsorption equilibrium studies were conducted in $250 \mathrm{~mL}$ Erlenmeyer flasks containing $100 \mathrm{~mL}$ of dye solution and $2.0 \mathrm{~g}$ of adsorbent. Assays were done in triplicate. The mixture was stirred in a shaker at $28{ }^{\circ} \mathrm{C}$ and $45{ }^{\circ} \mathrm{C}$ at a constant speed of $50 \mathrm{rpm}$ for $8 \mathrm{~h}$ at levels of 20-100 mg.L $\mathrm{L}^{-1}$ (pH 6.2). After equilibration, the mixture was immediately filtered using a vacuum pump filter. The RBBR concentration of each sample was determined by reading the absorbance in a spectrophotometer at $590 \mathrm{~nm}$.

The quantity of adsorbate adsorbed in the equilibrium

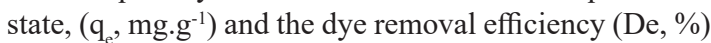
were determined using Equations (2) and (3), respectively.

$q_{e}=\frac{\left(C_{0}-C_{e}\right) * V}{m}$

where, $\mathrm{q}_{e}$ is the concentration of adsorbate taken up by the adsorbent $\left(\mathrm{mg} \cdot \mathrm{g}^{-1}\right)$ at equilibrium conditions, $\mathrm{C}_{\mathrm{o}}$ is the initial concentration of the compound (mg.L $\left.\mathrm{L}^{-1}\right), \mathrm{C}_{\mathrm{e}}$ is the equilibrium concentration of the solution $\left(\mathrm{mg} . \mathrm{L}^{-1}\right)$, $\mathrm{m}$ is the mass of the adsorbent $(\mathrm{g})$, and $\mathrm{V}$ is the solution volume $(\mathrm{L})$.

$\%$ Re moval $=\frac{\left(C_{0}-C_{t}\right)}{C_{0}} X 100$

where $D e$ is the efficiency of dye removal throughout of process (\%), $\mathrm{C}_{\mathrm{o}}$ and $\mathrm{C}_{\mathrm{t}}$ are the concentration of the dye compound (mg.L $\left.\mathrm{L}^{-1}\right)$ at the beginning of the process and at time $t$, respectively.

The results obtained from the adsorption isotherms were used to fit Langmuir's and Freundlich's adsorption models. The isotherm parameters, as well as the parameters of pseudo-first order and pseudo-second order models, were determined by linear regression using Microsoft Excel spreadsheet with Solver add-in.

\subsection{Experimental design}

To study the dye solution decolorization process and the production of oxidative enzymes, four, full-factorial experimental designs were carried out (ED1 - ED4) using the same explanatory factors: peach palm sheath quantity $(\mathrm{R})$, liquid phase (wastewater) volume (V), and the concentration of dye in the liquid phase (C). In all cases, the response variables were the efficiency of decolorization (De), laccase activity (La), and manganese peroxidase activity $(\mathrm{MnP})$. ED1 and ED2 were conducted using RBBR solution, ED3 was conducted with residual dyebath effluent, and ED4 with final effluent.

The factors and levels used in each series of experiments are shown in Table 1. The experimental matrix used for the different factorial designs is shown in Tables 2. The experimental results were used to fit a linear model which includes the main effects and interactions, as follows (Equation 4):

$\operatorname{Re}=a_{0}+a_{1} X+a_{2} Y+a_{3} Z+a_{4} X * Y+a_{5} X * Z+a_{6} Y * Z$

where: $\mathrm{X}, \mathrm{Y}$ and $\mathrm{Z}$ correspond to the explanatory factors, $a_{i}$ represents the model parameters, and Re represents the response variable.

Analysis of variance (ANOVA) and lack-of-fit tests were used to verify the adequacy of the model proposed for each response variable. Statistical analyses were performed using the Modde Software Package (Umetrics, Umea, Sweden).

Table 1. Factors and levels used on 6the Experimental Designs 1, 2, 3 and 4 (ED 1, 2, 3 and 4).

\begin{tabular}{lccc}
\hline \multirow{2}{*}{ Factors } & \multicolumn{3}{c}{ Level } \\
\cline { 2 - 4 } & $\mathbf{- 1}$ & $\mathbf{0}$ & $\mathbf{+ 1}$ \\
\hline ED1 & & & \\
\hline RBBR solution (mg/L) & 0 & 50 & 100 \\
Volume of the RBBR solution (mL) & 20 & 30 & 40 \\
Peach palm sheath (g) & 20 & 30 & 40 \\
\hline ED2 & & & \\
\hline RBBR solution (mg.L-1) & 0 & 100 & 200 \\
Volume of the RBBR solution (mL) & 20 & 40 & 60 \\
Peach palm sheath (g) & 10 & 20 & 30 \\
\hline ED3 and ED4 & & & \\
\hline RDB (ED3, \%) and FE (ED4, \%) & 0 & 50 & 100 \\
Volume of the wastewater (mL) & 20 & 40 & 60 \\
Peach palm sheath (g) & 10 & 20 & 30 \\
\hline
\end{tabular}

Table 2. Experimental matrix used for all the four Experimental Designs (ED1 to ED4).

\begin{tabular}{cccc}
\hline \multirow{2}{*}{$\begin{array}{c}\text { Assay } \\
\text { number }\end{array}$} & \multicolumn{3}{c}{ Levels of the codified factors } \\
\cline { 2 - 4 } & $\begin{array}{c}\text { Volume of } \\
\text { liquid phase } \\
(\mathbf{V})\end{array}$ & $\begin{array}{c}\text { Dye } \\
\text { concentration } \\
(\mathbf{C})\end{array}$ & $\begin{array}{c}\text { Quantity of } \\
\text { peach palm } \\
\text { residue (R) }\end{array}$ \\
\hline 1 & -1 & -1 & -1 \\
2 & 1 & -1 & -1 \\
3 & -1 & 1 & -1 \\
4 & 1 & 1 & -1 \\
5 & -1 & -1 & 1 \\
6 & 1 & -1 & 1 \\
7 & -1 & 1 & 1 \\
8 & 1 & 1 & 1 \\
9 & 0 & 0 & 0 \\
10 & 0 & 0 & 0 \\
11 & 0 & 0 & 0 \\
\hline
\end{tabular}




\subsection{Decolorization experiments}

Solid-state fermentation was carried out in 1 L flasks, as follows: (i) leaf sheaths was weighted and transferred to the flasks with $20 \mathrm{~mL}$ of a mineral medium (Leung and Pointing, 2002): (ii) flasks were autoclaved $\left(121^{\circ} \mathrm{C}\right.$ for 15 minutes) and previously autoclaved dye solution plus $1 / 6$ petri dish of fungal inoculum were introduced; (iii) cultivation took place at $28 \pm 2{ }^{\circ} \mathrm{C}$ in the dark.

After 14 days of processing, the entire content of the flasks was manually homogenized and a liquid extract (LE) was prepared by mixing $8 \mathrm{~g}$ sample with $50 \mathrm{~mL}$ of distilled water for 3 hours $\left(100 \mathrm{rpm}, 20 \pm 1{ }^{\circ} \mathrm{C}\right)$. The solids were then separated from the LE by vacuum filtration followed by centrifugation for $15 \mathrm{~min}$ at $4{ }^{\circ} \mathrm{C}(5,000 \mathrm{rpm})$. LEs were used to evaluate the efficiency of the decolorization process, enzymatic activity, biosurfactant presence, and the total concentration of phenolic compounds. For all assays, $\mathrm{pH}$ value and humidity were determined at the beginning (time zero) and at the end (after 14 days) of cultivation. The $\mathrm{pH}$ values were determined from a solution composed of $1.0 \mathrm{~g}$ of moistened solid substrate culture and $10 \mathrm{~mL}$ of distilled water.

The efficiency of decolorization was determined by comparing the initial value of wastewater dye absorbance to values at the end of the solid-state fermentation process. The measurements were carried out at maximum absorption of RBBR (593 nm).

\subsection{Laccase and manganese peroxidase activities}

Laccase activity was determined as described by Hou et al. (2004). Briefly, $0.1 \mathrm{~mL}$ of the LE preparations were transferred to test tubes with $0.8 \mathrm{~mL}$ of $2.2^{\prime}$-Azino-bis (3-ethylbenzthiazoline-6-sulfonic acid) (ABTS), $0.1 \mathrm{~mL}$ acetate buffer ( $\mathrm{pH} 4.0)$ and $0.1 \mathrm{~mL}$ of water. Control assays used $0.8 \mathrm{~mL}$ of ABTS with $0.1 \mathrm{~mL}$ of acetate buffer. Tubes were placed in the oven for 20 minutes at $30^{\circ} \mathrm{C}$. ABTS oxidation was monitored by measuring absorbance at $420 \mathrm{~nm}\left(\varepsilon=36 \mathrm{mM}^{-1} \mathrm{~cm}^{-1}\right)$ every 15 seconds for 2 minutes. Manganese peroxidase activity was carried out as reported by Wariishi et al. (1992).

Briefly, $0.4 \mathrm{~mL}$ hydrogen peroxide $[0.5 \mathrm{mM}]$ was added to a mixture composed of $0.4 \mathrm{~mL}$ of LE, $2.8 \mathrm{~mL}$ of sodium malonate buffer [50 mM] at $\mathrm{pH} 4.5$, and $0.4 \mathrm{~mL}$ [10 mM] manganese sulfate. The oxidation reaction of $\mathrm{MnSO} 4$ in sodium malonate buffer in the presence of $\mathrm{H}_{2} \mathrm{O}_{2}$ forms a complex with manganic ions $\left(\mathrm{Mn}^{3+}\right)$ and malonate, which show absorbance at $270 \mathrm{~nm}\left(\varepsilon=11.59 \mathrm{mM}^{-1} \mathrm{~cm}^{-1}\right)$.

For both enzymes, one unit of enzyme activity (U.L ${ }^{-1}$ ) was defined as the amount of enzyme oxidizing $1 \mu \mathrm{mol}$ of substrate per min ${ }^{-1}$. All experiments were carried out in triplicate.

\subsection{Moisture content}

Moisture content of the cultured samples was determined by a gravimetric method proposed by Hermann et al. (2013). Briefly, three samples (5.0 grams each) from the solid-state fermentation were weighted and dried at $60{ }^{\circ} \mathrm{C}$ until constant weight. The moisture content (MC) was calculated by the following Equation 5 .

$$
M C(\%)=\frac{M C_{i}-M C_{f}}{M C_{i}} \cdot 100
$$

where $\mathrm{MC}_{\mathrm{i}}$ and $\mathrm{MC}_{\mathrm{f}}$ correspond to the humidity values on the beginning (time zero) and after 14 days of solid-state fermentation, respectively.

\section{Results}

\subsection{Effect of potential adsorbent of peach palm residue}

Figure 1 show the amount of the dye adsorbed per unit weight of peach palm residue $\left(q_{t}\right)$ over $32 \mathrm{~h}$ of experiment. As it can be seen, the equilibrium of the process was reached at 8 hours of test, when the $\mathrm{q}_{\mathrm{t}}$ achieved a constant value of $1.8 \pm 0.1 \mathrm{mg}$. $\mathrm{g}^{-1}$. From 8 to $32 \mathrm{~h}$ of test, there is no tendency on $\mathrm{q}_{\mathrm{t}}$ over time. Thus, under these conditions, the residue was able to remove about of $72 \%$ of the dye present in the aqueous solution. Based on the values of correlation (Pearson) and determination $\left(\mathrm{R}^{2}\right)$ coefficients, the kinetic model which best described the experimental data was the pseudo-second order model.

Table 3 also presents the values of the parameters of Langmuir and Freundlich isotherms, as well the Pearson $r$ (correlation coefficient) and $\mathrm{R}^{2}$ values. The experimental data are consistent with both isothermal models. The Langmuir isotherm is specific for monolayer adsorption, wherein the adsorbent consists of active surface sites with equal energies available for adsorption. Independently of temperature, the values found for separation parameter $\left(R_{L}\right)$ where always higher to zero and lower to 1 , indicating a favorable adsorption of peach palm residue-RBBR system. On the other hand, the Freundlich isotherm is best applied to heterogeneous adsorption sites.

Isotherm equilibrium is an important factor in the development of adsorption processes, and is used to describe how the adsorbate molecules interact with active sites on the adsorbent. The dye equilibrium data for RBBR were assembled using the Langmuir (Rahchamani et al., 2011) and Freundlich (Chiang and Wu, 2010) isotherms. The experimental data are consistent with both isothermal models. The Langmuir isotherm is specific for monolayer adsorption, wherein the adsorbent consists of active surface sites with equal energies available for adsorption. Independently of temperature, the values found for the separation parameter $\left(\mathrm{R}_{\mathrm{L}}\right)$ where always higher to zero and

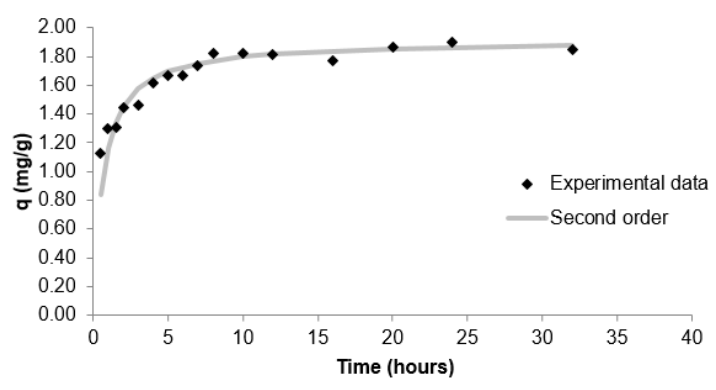

Figure 1. Experimental data based on adsorption kinetics expressions. 
lower to 1 , indicating a favorable adsorption of peach palm residue-RBBR system. On the other hand, the Freundlich isotherm is best applied to heterogeneous adsorption sites (Isah A et al., 2015).

\subsection{Solid-state fermentation experiments with remazol brilliant blue $R$}

The effect of RBBR concentration ( 0 - 100\%), liquid phase volume $(20-60 \mathrm{~mL})$, and palm sheath quantity $(10-30 \mathrm{~g})$ on decolorization percentage is shown in Figure 2.

RBBR was efficiently decolorized by G. lucidum, reaching efficiency values near $97 \%$. The contour curves for
ED1 were generated using Equations 6 and 7 respectively, which were obtained from the fitting of experimental data.

$$
\begin{aligned}
& D e(\%)=2.180 * 10^{-5}-8.177 * 10^{-7} V+0.948 C+ \\
& 4.237 * 10^{-8} R+0.002 V^{*} C-0.004 C^{*} R \\
& L a\left(U L^{-1}\right)=-21.508+2.232 V+0.414 C+ \\
& 0.50827 R-0.0528 V * R-0.0109 C^{*} R
\end{aligned}
$$

Both ANOVA and the lack-of-fit test confirmed the

\begin{tabular}{|c|c|c|c|}
\hline Kinetic models & Variables & & Peach palm \\
\hline \multirow{5}{*}{$\begin{array}{l}\text { Pseudo } 1^{\mathrm{a}} \text { Order } \\
\log (q e q-q t)=\log q e q \frac{K 1 x t}{2.303}\end{array}$} & $\mathrm{~K}_{1}\left(\min ^{-1}\right)$ & & 0.150 \\
\hline & $\mathrm{Q}_{\mathrm{eq}}\left(\mathrm{mg} \cdot \mathrm{g}^{-1}\right)$ & & 1.538 \\
\hline & $\mathrm{Q}_{\mathrm{eqExp}}\left(\mathrm{mg} \cdot \mathrm{g}^{-1}\right)$ & & 1.920 \\
\hline & $\mathrm{R}^{2}$ & & 0.946 \\
\hline & Pearson $r$ & & 0.973 \\
\hline \multirow[b]{2}{*}{ Pseudo $2^{\mathrm{a}}$ Order } & $\mathrm{K}_{2}\left(\min ^{-1}\right)$ & & 0.817 \\
\hline & $\mathrm{Q}_{\mathrm{eq}}\left(\mathrm{mg} \cdot \mathrm{g}^{-1}\right)$ & & 1.912 \\
\hline \multirow{3}{*}{$\frac{t}{q t}=\frac{1}{k_{2} q_{e q}^{2}}+\frac{t}{q_{e q}}$} & $\mathrm{Q}_{\text {eqExp }}\left(\mathrm{mg} \cdot \mathrm{g}^{-1}\right)$ & & 1.920 \\
\hline & $\mathrm{R}^{2}$ & & 0.998 \\
\hline & Pearson $r$ & & 0.999 \\
\hline \multirow{4}{*}{$\begin{array}{l}\text { Intraparticle diffusion } \\
q t=K_{i d} t^{1 / 2}+C i\end{array}$} & $\mathrm{~K}_{\mathrm{id}}\left(\mathrm{mg} \cdot \mathrm{g}^{-1} \mathrm{~min}^{-1 / 2}\right)$ & & 0.173 \\
\hline & $\mathrm{C}_{\mathrm{i}}\left(\mathrm{mg} \cdot \mathrm{g}^{-1}\right)$ & & 1.178 \\
\hline & $\mathrm{R}^{2}$ & & 0.838 \\
\hline & Pearson $r$ & & 0.916 \\
\hline Isothermal & Variables & $28^{\circ} \mathrm{C}$ & $45^{\circ} \mathrm{C}$ \\
\hline Langmuir & $\mathrm{q}_{\max }\left(\mathrm{mg} \cdot \mathrm{g}^{-1}\right)$ & 5.757 & 25.641 \\
\hline \multirow{2}{*}{$\frac{C_{e q}}{a}=\frac{1}{q}+\frac{C_{e q}}{q}$} & B (L.mg $\left.{ }^{-1}\right)$ & 0.030 & 0.007 \\
\hline & $\mathrm{R}^{2}$ & 0.841 & 0.891 \\
\hline$q_{e q} \quad q_{m^{b}} \quad q_{m}$ & Pearson $\mathrm{r}$ & 0.970 & 0.944 \\
\hline Freundlich & $\mathrm{K}_{\mathrm{f}}\left(\mathrm{mg} \cdot \mathrm{g}^{-1}\right)$ & 0.114 & 0.160 \\
\hline \multirow{3}{*}{$\log q_{e q}=\log K_{f}+\left(\frac{1}{n}\right) \log C_{e q}$} & $1 / \mathrm{n}$ & 1.356 & 1.079 \\
\hline & $\mathrm{R}^{2}$ & 0.996 & 0.999 \\
\hline & Pearson $r$ & 0.998 & 1.000 \\
\hline
\end{tabular}
validity of both mathematical models. The significance of the model parameters from Equations 6 and 7 are listed in

Table 3. Kinetic and Isothermal models for adsorption of RBBR dye (Remazol Brilliant Blue R) on peach palm sheath.

$\mathrm{q}_{\mathrm{te}} \mathrm{q}_{\mathrm{eq}}=$ quantity adsorbed at time $\mathrm{t}$ and the balance of time respectively; $\mathrm{K}_{1}$ and $\mathrm{K}_{2}=$ constants of pseudo first and second order, respectively; $\mathrm{K}_{\mathrm{id}}=$ constant rate of intraparticle diffusion; $\mathrm{C}=$ constant indicating the effect of the boundary layer. ${ }^{2} \mathrm{q}_{\max }=$ maximum amount of adsorbate per unit mass of the biosorbents; $b=$ adsorption equilibrium constant; $\mathrm{k}_{\mathrm{f}}=$ Freundlich constants.
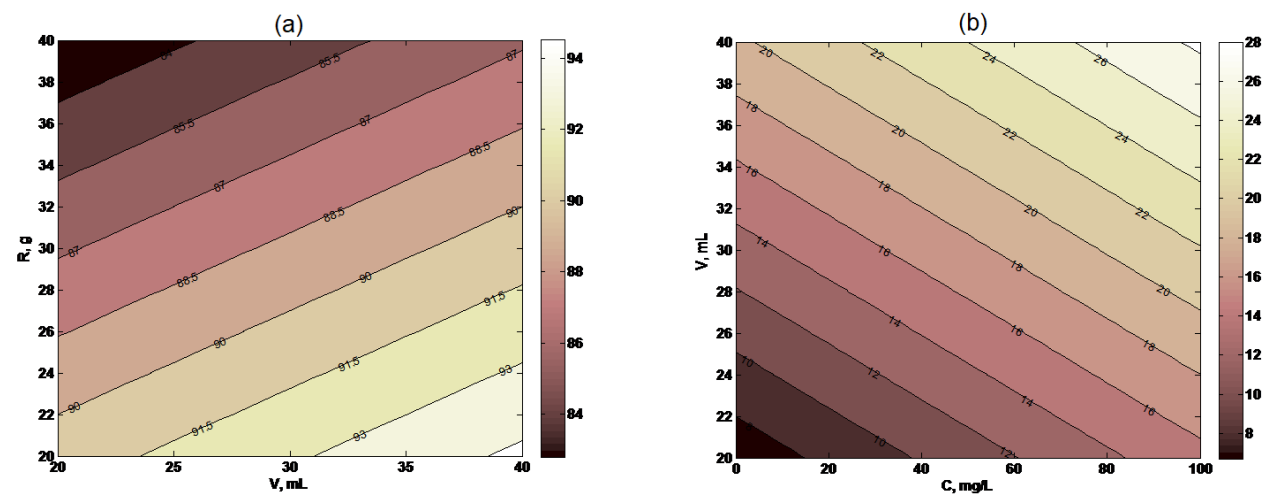

Figure 2. Contour plots for ED1: (a) Predicted De values at different liquid volumes of the dye (mL) and peach palm sheath quantities $(\mathrm{g})(\mathrm{C}=100 \%)$; (b) Predicted La values at different liquid volumes of the dye $(\mathrm{mL})$ and RBBR concentrations $(\%)(\mathrm{R}=30 \mathrm{~g})$. 
Table 4. If the p-value of the coefficient was lower than 0.05 , it was considered statistically significant and was retained in the mathematical model. Factors with p-values higher than 0.05 , were removed from the model. Although $\mathrm{V}, \mathrm{R}$, and $\mathrm{C}$ all had significant effects on decolorization percentages, the most important factor for dye removal was $\mathrm{RBBR}$ concentration, followed by liquid phase volume and peach palm sheath quantity. The $\mathrm{V}^{*} \mathrm{C}$ and $\mathrm{C}^{*} \mathrm{R}$ interactions were significant, and experimental data indicate that in the range of 0 to $100 \mathrm{mg} \mathrm{L}^{-1} \mathrm{RBBR}$, the increased dye concentration leads to higher De values.

Laccase and manganese peroxidase enzymes production was also significantly affected by the three main factors, with some significant interactions among factors. Optimal response conditions were obtained through the regression model. Table 4 summarizes the experimental conditions which resulted in the highest production of enzymes and efficacy of decolorization. There is a clear relationship between the degradation of the dye and enzymatic activity with RBBR concentrations between 0 to $100 \mathrm{mg} . \mathrm{L}^{-1}$. The highest De values and greatest enzyme production were obtained with $100 \mathrm{mg} . \mathrm{L}^{-1}$ of dye solution (level 0 ) and $20 \mathrm{~g}$ of peach palm sheath (level -1). The greatest decolorization values (predicted as 93.97\%) also coincide with the highest laccase activity (53.94 U. L-1).

The ED2 results are in strong agreement with those of ED1. The highest De value (96.1\%) was achieved when
$10 \mathrm{~g}$ of peach palm sheath was moistened with $60 \mathrm{~mL}$ of $200 \mathrm{mg} . \mathrm{L}^{-1}$ RBBR solution (see Table 5). Hence, no inhibitory effect on the color removal was observed at concentrations in the range of 100 to $200 \mathrm{mg} \cdot \mathrm{L}^{-1}$. Compared to ED1, laccase production was more affected by dye concentration.

Our results indicate that RBBR concentration exerts a significant and positive effect on laccase production. $\mathrm{MnP}$ activities cannot be satisfactorily fitted by the mathematical model proposed in Equation 4, which yielded the highest experimental value $\left(0.24 \pm 0.9\right.$ U.L $\left.{ }^{-1}\right)$ using $200 \mathrm{mg} . \mathrm{L}^{-1}$.

\subsection{Solid-state fermentation carried out with industrial wastewaters}

The highest decolorization values ( $76 \%$ and $73 \%)$ from solid state fermentation were obtained using $60 \mathrm{~mL}$ of the final effluent (100\%) and 10 grams of peach palm sheath.

Hence, the experimental De values found for the final effluent are thus at least $20 \%$ lower than those found with RBBR solutions (ED1). This is likely because the final effluent is a complex mixture of several compounds, such us organic compounds, metals, and salts. Unexpectedly, decolorization did not occur in residual dyebath effluent regardless of experimental conditions (see ED3). This suggests that treating the whole textile effluent is better than treating effluent produced exclusively by the dyeing operation. This could be because the final wastewater comes from

Table 4. ED1: Model parameters and corresponding p-values for Experimental Design 1 (ED1).

\begin{tabular}{|c|c|c|c|c|}
\hline ED1 & Coeff. SC & Std. Err. & p-value & Conf. Int. $( \pm)$ \\
\hline \multicolumn{5}{|c|}{ Decolorization efficiency $\left(\mathbf{R}^{2}=\mathbf{0 . 9 9 9}\right)$} \\
\hline Constant & 44.5097 & 0.330774 & $3.44259 \mathrm{e}-023$ & 0.709445 \\
\hline $\mathbf{V}$ & 0.752497 & 0.339278 & 0.0436077 & 0.727686 \\
\hline $\mathbf{C}$ & 44.6309 & 0.338942 & $4.66201 \mathrm{e}-023$ & 0.726965 \\
\hline $\mathbf{R}$ & -1.5725 & 0.339278 & 0.000386031 & 0.727686 \\
\hline $\mathbf{V} * \mathbf{C}$ & 0.752499 & 0.339278 & 0.0436072 & 0.727686 \\
\hline $\mathbf{V} * \mathbf{R}$ & 0.0289979 & 0.332423 & 0.931722 & 0.712983 \\
\hline $\mathbf{C} * \mathbf{R}$ & -1.5725 & 0.339278 & 0.000386027 & 0.727686 \\
\hline \multicolumn{5}{|c|}{ Laccase activity $\left(R^{2}=0.925\right)$} \\
\hline Constant & 17.4062 & 1.02717 & $1.64739 \mathrm{e}-012$ & 2.158 \\
\hline V & 6.33277 & 1.14569 & $3.00839 \mathrm{e}-005$ & 2.40701 \\
\hline $\mathbf{C}$ & 4.14236 & 1.14569 & 0.00197738 & 2.40701 \\
\hline $\mathbf{R}$ & -16.1646 & 1.15477 & $4.07447 \mathrm{e}-011$ & 2.42608 \\
\hline$V^{*} \mathbf{C}$ & -1.03864 & 1.1239 & 0.36764 & 2.36123 \\
\hline $\mathbf{V} * \mathbf{R}$ & -5.13527 & 1.14569 & 0.000288063 & 2.40701 \\
\hline $\mathbf{C}^{*} \mathbf{R}$ & -5.32819 & 1.14569 & 0.000198854 & 2.40701 \\
\hline \multicolumn{5}{|c|}{ Manganese peroxidase activity $\left(\mathrm{R}^{2}=0.912\right)$} \\
\hline Constant & 2.44257 & 0.21775 & $2.21214 \mathrm{e}-008$ & 0.467032 \\
\hline $\mathbf{V}$ & -1.85731 & 0.229301 & $1.18488 \mathrm{e}-006$ & 0.491806 \\
\hline $\mathbf{C}$ & 0.803526 & 0.227196 & 0.00328655 & 0.487291 \\
\hline $\mathbf{R}$ & -1.30894 & 0.229301 & $5.4054 \mathrm{e}-005$ & 0.491806 \\
\hline $\mathbf{V}^{*} \mathbf{C}$ & -0.971897 & 0.229301 & 0.000826337 & 0.491806 \\
\hline $\mathbf{V} * \mathbf{R}$ & 1.16899 & 0.229085 & 0.000160849 & 0.491343 \\
\hline $\mathbf{C} * \mathbf{R}$ & 0.0731471 & 0.229301 & 0.754436 & 0.491806 \\
\hline
\end{tabular}

Highest values of decolorization, laccase and manganese peroxidase activity in all Experimental Designs (ED). Where: $\mathrm{V}=$ volume of liquid phase; $\mathrm{C}=$ dye concentration; $\mathrm{R}=$ quantity of the residue. 
Table 5. Highest values of decolorization laccase and manganese peroxidase activity in all Experimental Designs (ED).

\begin{tabular}{|c|c|c|c|c|c|c|c|}
\hline \multirow{2}{*}{ ED } & \multirow{2}{*}{ Dye } & \multirow{2}{*}{ Factors } & \multirow{2}{*}{ Responses } & \multirow{2}{*}{$\begin{array}{l}\text { Highest } \\
\text { predicted } \\
\text { value }\end{array}$} & \multicolumn{3}{|c|}{ Factors (values decodified) } \\
\hline & & & & & $\mathbf{V}(\mathbf{m L})$ & $\mathrm{C}\left(\mathrm{mg} \mathrm{L}^{-1}\right)$ & $\mathbf{R}(\mathrm{g})$ \\
\hline \multirow[t]{3}{*}{ ED1 } & RBBR & $\mathrm{V}, \mathrm{C}$ and $\mathrm{R}$ & De (\%) & 95.6 & 40.0 & 100.0 & 20.0 \\
\hline & & & $\mathrm{La}\left(\mathrm{U}^{\mathrm{L}} \mathrm{L}^{-1}\right)$ & 53.5 & 40.0 & 100.0 & 20.0 \\
\hline & & & $\operatorname{MnP}\left(U \cdot L^{-1}\right)$ & 8.7 & 20.0 & 100.0 & 20.0 \\
\hline \multirow[t]{3}{*}{ ED2 } & RBBR & $\mathrm{V}, \mathrm{C}$ and $\mathrm{R}$ & De $(\%)$ & 96.1 & 60.0 & 200.0 & 10.0 \\
\hline & & & $\mathrm{La}\left(\mathrm{U} . \mathrm{L}^{-1}\right)$ & 38.6 & 60.0 & 200.0 & 10.0 \\
\hline & & & $\operatorname{MnP}\left(U \cdot L^{-1}\right)$ & Lof & -- & -- & -- \\
\hline \multirow[t]{3}{*}{ ED3 } & Dyebath & $\mathrm{V}, \mathrm{C}$ and $\mathrm{R}$ & De (\%) & Lof & --- & --- & --- \\
\hline & effluent & & $\mathrm{La}\left(\mathrm{U} . \mathrm{L}^{-1}\right)$ & 38.2 & 60.0 & 0.0 & 10.0 \\
\hline & & & $\operatorname{MnP}\left(\mathrm{U}^{-L^{-1}}\right)$ & Lof & -- & --- & -- \\
\hline \multirow[t]{3}{*}{ ED4 } & Final & $\mathrm{V}, \mathrm{C}$ and $\mathrm{R}$ & De $(\%)$ & Lof & --- & --- & --- \\
\hline & effluent & & $\mathrm{La}\left(\mathrm{U} . \mathrm{L}^{-1}\right)$ & 43.8 & 60.0 & 0.0 & 10.0 \\
\hline & & & $\operatorname{MnP}\left(\mathrm{U}^{-L^{-1}}\right)$ & Lof & --- & --- & -- \\
\hline
\end{tabular}

Where: $\mathrm{V}=$ volume of liquid phase; $\mathrm{C}=$ dye concentration; $\mathrm{R}=$ quantity of the residue.

all of the industrial processes that utilize water, and it is therefore much more dilute than the residual dyebath effluent.

The experimental De values for ED3 and ED4 cannot be adequately described by the mathematical model presented in Equation 4. In both cases, the lack-of-fit test was significant at the $95 \%$ confidence level. Equations 6 and 7, however, were suitable to describe the experimental values of laccase activity in ED3 and ED4, respectively. Factors that did not affect laccase activity (non-significant terms) were excluded from the models. Since the adequacy of both models was verified by an analysis of variance (ANOVA) and a lack-of-fit test, and hence, the models are adequate for use in predicting outcomes within the experimental intervals tested. It is worth noting that: (i) all terms presented in Equations 8 and 9 significantly affected laccase production and, (ii) the parameters which exhibit a significant effect on La are the same in both experimental designs.

$$
\begin{aligned}
& L a_{D O E 3}=7.836+0.550 H+0.139 W- \\
& 0.2618 R-0.008 H * R \\
& L a_{D O E 4}=23.3325+0.412 H-0.148 W- \\
& 0.429 R-0.004 H * R
\end{aligned}
$$

For both the final effluent and the residual dyebath wastewater (ED3 and ED4, Table 6), the highest predicted values of La were reached using volumes of wastewater or dye solution near $60 \mathrm{~mL}, 10 \mathrm{~g}$ of peach palm sheath, and wastewater concentrations less than or equal to $11 \%$.

No manganese peroxidase production was detected in the experiments performed with the industrial effluents, as also described Pedri et al. (2015). A low production of $\mathrm{MnP}$ was also previously observed in the RBBR assays. The ANOVA for multiple regression showed no significant relationships ( $p$-value $>0.05$ ) between the main factors and the MnP activity. Low production of MnP was previously observed in the RBBR assays.

Moisture content for SSF is usually defined during the initial substrate preparation prior the inoculation with white-rot fungi, and its optimum value depends on the microorganism and the substrate employed (Isroi et al., 2011). After our initial determination, the experimental $\mathrm{MC}$ values were used to fit Equation 4 for each of the experimental designs. In all cases, MC values were significantly affected by liquid phase volume and peach palm residue quantity. Interestingly, the experimental conditions that lead to higher moisture content (for example, $83 \%$ in ED3) coincide with the higher production of laccase.

\section{Discussion}

The experimental data suggests that the solid substrate not only provides a similar environment to the natural habitat of the fungi (Boran and Yesilada, 2011), enhancing the production of laccase, but also acts as an efficient dye adsorbent. The interactions between dyes and lignocellulose fibers, has received considerable attention. Peach palm sheaths are composed of $21.65 \%$ lignin, and $73.51 \%$ holocellulose (hemicellulose and cellulose). Cationic dyes no doubt have a higher affinity for the lignin-containing fibers than for the anionic dyes, and the presence of positive charge is undoubtedly an importance factor for dye affinity for lignin (Drnovsek and Perdih, 2005). In addition, RBBR dyes have an electrophilic reactive group which is capable of forming covalent bonds with hydroxyl groups from the cellulose fibers.

Laccases have a broad substrate range and act with low specificity on o-phenols and p-phenols via transfer of four electrons from the organic substrate to molecular oxygen. Such behavior may be due to laccase abstraction of a phenol electron as a function of reducing $\mathrm{Cu}^{2+}$ to $\mathrm{Cu}^{1+}$. That in turn reduces $\mathrm{O}_{2}$ to $\mathrm{H}_{2} \mathrm{O}$, allowing the enzyme to act cyclically if phenols are present and conditions are suitable (e.g., acceptable $\mathrm{pH}$ ). Solid-state fermentation is thus a stable process. The equilibrium of the system occurs through biochemical mechanisms of aromatic molecule degradation by dye enzymes, which develop oxidation-reduction reactions in fungal cells such as laccases (Kües, 2015; Sarkar et al., 2014; Özcan et al., 2005). 
Table 6. Experimental results of De, La and MnP obtained in ED3 and ED4 Experimental Designs.

\begin{tabular}{|c|c|c|c|c|c|c|c|c|c|c|c|c|}
\hline \multirow[b]{2}{*}{ Assay } & \multicolumn{3}{|c|}{ Factors } & \multicolumn{3}{|c|}{ De-exp (\%) } & \multicolumn{3}{|c|}{ La-exp (U.L. $\left.\mathbf{L}^{-1}\right)$} & \multicolumn{3}{|c|}{ MnP-exp (U.L $\left.{ }^{-1}\right)$} \\
\hline & $\begin{array}{c}V \\
(m L)\end{array}$ & $\mathrm{C}(\%)$ & $\begin{array}{l}\mathbf{R} \\
(\mathrm{g})\end{array}$ & $\mathbf{R} 1$ & $\mathbf{R 2}$ & R3 & R1 & $\mathbf{R 2}$ & R3 & R1 & $\mathbf{R 2}$ & R3 \\
\hline \multicolumn{13}{|c|}{$\operatorname{ED3}(\mathrm{pHi}=11.2 \pm 0.4)$} \\
\hline 1 & 20 & 0 & 10 & 0 & 0 & ND & 13.54 & 17.29 & ND & 0 & 0 & ND \\
\hline 2 & 60 & 0 & 10 & 0 & 0 & ND & 41.76 & 31.88 & 15.43 & 0 & 0 & ND \\
\hline 3 & 20 & 100 & 10 & 0 & 0 & ND & 14.06 & ND & ND & 0 & 0 & ND \\
\hline 4 & 60 & 100 & 10 & 0 & 0 & ND & 0.00 & ND & ND & 0 & 0 & ND \\
\hline 5 & 20 & 0 & 30 & 0 & 0 & ND & 13.01 & 16.05 & 18.00 & 0 & 0 & ND \\
\hline 6 & 60 & 0 & 30 & 0 & 0 & ND & 32.10 & 29.82 & 39.07 & 0 & 0 & ND \\
\hline 7 & 20 & 100 & 30 & 0 & 0 & ND & 0.00 & ND & ND & 0 & 0 & ND \\
\hline 8 & 60 & 100 & 30 & 0 & 0 & ND & 0.00 & ND & ND & 0 & 0 & ND \\
\hline 9 & 40 & 50 & 20 & 0 & 0 & 0 & 15.10 & 16.66 & 15.92 & 0 & 0 & ND \\
\hline \multicolumn{13}{|c|}{ ED4 $(\mathrm{pHi}=9.7 \pm 0.0)$} \\
\hline 1 & 20 & 0 & 10 & 0 & 0 & ND & 29.24 & 27.01 & ND & 0.000 & 0.56 & ND \\
\hline 2 & 60 & 0 & 10 & 0 & 0 & ND & 40.68 & 56.19 & ND & 0.09 & ND & ND \\
\hline 3 & 20 & 100 & 10 & 65.78 & 63.21 & ND & 1.94 & 3.89 & ND & 0.34 & 0.30 & ND \\
\hline 4 & 60 & 100 & 10 & 76.05 & 72.91 & ND & 2.64 & 2.08 & 5.63 & 0 & 0 & ND \\
\hline 5 & 20 & 0 & 30 & 0 & 0 & ND & 14.79 & 24.24 & 21.67 & 0 & 0 & ND \\
\hline 6 & 60 & 0 & 30 & 0 & 0 & ND & 29.03 & 31.67 & ND & 0 & 0 & ND \\
\hline 7 & 20 & 100 & 30 & 0 & 0 & ND & 0.00 & ND & ND & 0 & 0 & ND \\
\hline 8 & 60 & 100 & 30 & 68.06 & 66.92 & ND & 0.00 & ND & ND & 0 & 0 & ND \\
\hline 9 & 40 & 50 & 20 & 0 & 0 & 0 & 16.81 & 11.02 & 10.18 & 0.04 & 0 & ND \\
\hline
\end{tabular}

$\mathrm{ND}=$ Not Detected.

Hence, no inhibitory effect on the color removal was observed at concentrations in the range of 100 to $200 \mathrm{mg} \mathrm{L}^{-1}$ with the RBBR (ED2). But, when is compared to ED1, laccase production was more affected by dye concentration. This behavior as also found in a study by (Mohan et al., 2005 ) in which the aqueous phase substrate concentration significantly influences the reaction mediated by the enzyme. If the enzyme concentration is held constant and the concentration of substrate is gradually increased, the reaction rate will increase until reaching the maximum value. After reaching balance, any added substrate will not change the rate of reaction.

Murugesan et al. (2007) evaluated dye decolorization by G. lucidum KMK2, and found that when using pure laccase, De increased for RBBR concentrations up to $300 \mathrm{mg} \mathrm{L}^{-1}$, then decreased at higher RBBR concentrations. Our results indicate that RBBR concentration exerts a significant and positive effect on laccase production.

De values for the final effluent are thus at least $20-30 \%$ lower than those found with RBBR solutions (ED1). This is likely because the final effluents contain organic compounds, metals, and salts that directly affect water color, have chemical and biochemical oxygen demand (COD/BOD), have high quantity of total dissolved solid (TDS) and total suspended solid (TSS), and basic pH (Kabra et al., 2013). Unexpectedly, decolorization did not occur in residual dyebath effluent regardless of experimental conditions. This suggests that treating the whole textile effluent is better than treating effluent produced exclusively by the dyeing operation. This could be because the final wastewater comes from all of the industrial processes that utilize water, and it is therefore much more dilute than the residual dyebath.

Several studies report decolorization by laccases, but also indicate that the $\mathrm{pH}$ and moisture conditions dictate the success of the process. Our data on final and residual dyebath effluent show that the extract $\mathrm{pH}$ remained constant after 14 days of solid state fermentation. However, in the RBRR treatments the $\mathrm{pH}$ of the extracts varied from $2.4 \pm 0.1$ (time zero) to $4.3 \pm 0.2$ regardless of experimental conditions. The phenomenon of the $\mathrm{pH}$ elevation has been previously reported at the literature and might be related to ability of some white rot fungi to reduce substrate acidity under certain conditions (Zadražil and Brunnet, 1981; Chicatto et al., 2014).

The literature is replete with reports demonstrating the excellent capacity of fungi to degrade dyes, but their potential use in real industrial applications has been limited for various reasons. First, it has proven difficult to select organisms that are capable of growth and degradation in the highly variable and restrictive conditions of textile industry wastewaters. Second, most studies have focused on single model dyes at low concentrations, and these conditions cannot accurately predict or represent the decolorization efficiency of real effluents in which dyes are usually present as mixtures and often, at high concentrations. Moreover, biotransformation of model dyes cannot always be extrapolated to industrial dyes (Lucas et al., 2008), and most studies on dye degradation are conducted at Erlenmeyer scale. Before an industrial 
application can be implemented, fungal bioreactors which can be operated under industrial conditions using real wastewaters must be developed (Anastasi et al., 2010). In this sense, this is the first report on laccase production in G. lucidum on peach palm sheaths moistened with industrial dye wastewater. This study will provide the basis for the solid-state fermentation reactor in fixed bed (Packed bed reactors, Patent BR 20201200192 (Hermann et al., 2012)) for decolorization of textile wastewater, given the capacity of the peach palm sheath act as an adsorbent of dyes and concomitantly, as a substrate for basidiomycetes fungal hyphae which degrade xenobiotic compounds. This study provides new perspectives for up-scaling the process of textile dye decolorization using white-rot fungi and peach palm sheaths. The peach palm sheath functions well in solid-state fermentation, supporting the development of fungal hyphae and production of oxidative enzymes. Our results suggest that palm sheaths have considerable potential in the process of RBBR dye removal via degradation through G. lucidum enzymes.

\section{Acknowledgements}

This work was supported by the Brazilian Ministry of Science, Technology and Innovation (MCTI) (Grant 402593/2013-8). The project was funded through scholarships provided by the Coordination for the Improvement of Higher Education Personnel (CAPES) and National Council for Scientific and Technological Development (CNPq). L.B.B. Tavares also holds a fellowship from CNPq.

\section{References}

ABULNAJA, K.O. and ABOU-ZEID, A.A., 1993. Utilization of palm-tree compound leaves in formation of cellulases. Bioresource Technology, vol. 44, no. 3, pp. 255-257. http://dx.doi. org/10.1016/0960-8524(93)90160-D.

ANASTASI,A., SPINA, F., PRIGIONE, V., TIGINI, V., GIANSANTI, P. and VARESE, G.C., 2010. Scale-up of a bioprocess for textile wastewater treatment using Bjerkandera adusta. Bioresource Technology, vol. 101, no. 9, pp. 3067-3075. PMid:20071167. http://dx.doi.org/10.1016/j.biortech.2009.12.067.

ASGHER, M., IQBAL, H.M.N. and IRSHAD, M., 2012. Characterization of purified and Xerogel immobilized Novel Lignin Peroxidase produced from Trametes versicolor IBL-04 using solid-state medium of corncobs. BMC Biotechnology, no. 12(2012), pp. 46. PMid:22862820. http://dx.doi.org/10.1186/14726750-12-46.

BORAN, F. and YESILADA, O., 2011. Enhanced production of laccase by fungi under solid substrate fermentation condition. BioResource, vol. 6, pp. 4404-4416.

CHIANG, Y.C. and WU, P.Y., 2010. Adsorption equilibrium of sulfur hexafluoride on multi-walled carbon nanotubes. Journal of Hazardous Materials, vol. 178, no. 1-3, pp. 729-738. PMid:20185236. http://dx.doi.org/10.1016/j.jhazmat.2010.02.003.

CHICATTO, J.A., COSTA, A., NUNES, H., HELM, C.V. and TAVARES, L.B.B., 2014. Evaluation of hollocelulase production by Lentinula edodes (Berk.) Pegler during the submerged fermentation growth using RSM. Brazilian Journal of Biology = Revista Brasileira de Biologia, vol. 74, no. 1, pp. 243-250. PMid:25055110. http://dx.doi.org/10.1590/1519-6984.21712.

DRNOVSEK, T. and PERDIH, A., 2005. Selective staining as a tool for wood fibre characterization. Dyes and Pigments, vol. 67, no. 3, pp. 197-206. http://dx.doi.org/10.1016/j.dyepig.2004.10.013.

EL-BATAL, A.I., EL-KENAWY, N.M., YASSIN, A.S. and AMIN, M.A., 2015. Laccase production by Pleurotus ostreatus and its application in synthesis of gold nanoparticles. Biotechnology Reports, vol. 5, pp. 31-39. PMid:28626680. http://dx.doi. org/10.1016/j.btre.2014.11.001

GREGORY, P., 1990. Classification of dyes by chemical structure. In: D. Waring and G. Hallas, eds. The chemistry and application of dyes cart of the series topics in applied chemistry. 2nd ed. New York: Plenun Press, pp. 17.

GUIZA, S., GHILOUFI, K. and BAGANE, F.M., 2014. Utilization of waste Tunisian palm tree date as low-cost adsorbent for the removal of dyes from textile wastewater. Mediterranean Journal of Chemistry, vol. 3, no. 5, pp. 1044-1052.

HELM, C.V., RAUPP, D.S. and SANTOS, A.F., 2014. Development of peach palm fibrous flour from the waste generated by the heart of palm agribusiness. Acta Scientiarum. Technology, vol. 36, no. 1, pp. 171-177. http://dx.doi.org/10.4025/17165.

HERMANN, K.L., COSTA, A., HELM, C.V., LIMA, E.A. and TAVARES, L.B., 2013. Expression of manganese peroxidase by Lentinula edodes and Lentinula boryana in solid state and submerged system fermentation. Anais da Academia Brasileira de Ciencias, vol. 85, no. 3, pp. 965-973. PMid:24068086. http:// dx.doi.org/10.1590/S0001-37652013000300009.

HERMANN, K.L., VEGINI, A.A., COSTA, A., TAVARES, L.B.B. and GUEDES, F.F., 2012. Filtro de biomassa em camada para remoção de corante e processo de descolorimento de efluente utilzando filtro de biomassa em camada. Patent BR 20201200192. Florianópolis: FAPESC. In Portuguese.

HOU, H., ZHOU, J., WANG, J., DU, C. and YAN, B., 2004. Enhancement of laccase production by Pleurotus ostreatus and its use for the decolorization of anthraquinone dye. Process Biochemistry, vol. 39, no. 11, pp. 1415-1419. http://dx.doi. org/10.1016/S0032-9592(03)00267-X

INSTITUTO BRASILEIRO DE GEOGRAFIA E ESTATÍSTICA - IBGE, 2015 [viewed 15 December 2016]. Censo Agropecuário 2015 [online]. Available from: https://www.ibge.gov.br/home/ estatistica/economia/forum questionario censoagro2015/ Censo_Agropecuario_2015.pdf

ISAH A, U., ABDULRAHEEM, G., BALA, S., MUHAMMAD, S. and ABDULLAHI, M., 2015. Kinetics, equilibrium and thermodynamics studies of CI Reactive Blue 19 dye adsorption on coconut shell based activated carbon. International Biodeterioration \& Biodegradation, vol. 102, pp. 265-273. http://dx.doi.org/10.1016/j. ibiod.2015.04.006.

ISROI, I., MILLATI, R., SYAMSIAH, S., NIKLASSON, C., CAHYANTO, M.N., LUDQUIST, K., and TAHERZADEH, M.J., 2011. Biological pretreatment of lignocelluloses with white-rot fungi and its applications: a review. BioResources, vol. 6, pp. 5224-5259.

JAOUANI, A., SAYADI, S., VANTHOURNHOUT, M. and PENNINCKX, M.J., 2003. Potent fungi decolorization of olive mill wastewater. Enzyme and Microbial Technology, vol. 33, no. 6, pp. 802-809. http://dx.doi.org/10.1016/S0141-0229(03)00210-2. 
KABRA, A.N., KHANDARE, R.V. and GOVINDWAR, S.P., 2013. Development of a bioreactor for remediation of textile effluent and dye mixture: a plant-bacterial synergistic strategy. Water Research, vol. 47, no. 3, pp. 1035-1048. PMid:23245543. https://doi.org/10.1016/j.watres.2012.11.007

KÜES, U., 2015. Fungal enzymes for environmental management. Current Opinion in Biotechnology, vol. 33, pp. 268-278. PMid:25867110. http://dx.doi.org/10.1016/j.copbio.2015.03.006.

KUHAR, F., CASTIGLIA, V. and LEVIN, L., 2015. Enhancement of laccase production and malachite green decolorization by coculturing Ganoderma lucidum and Trametes versicolor in solid-state fermentation. International Biodeterioration \& Biodegradation, vol. 104, pp. 238-243. http://dx.doi.org/10.1016/j.ibiod.2015.06.017.

LEUNG, P.C. and POINTING, S.B., 2002. Effect of different carbon and nitrogen regimes on Poly R decolorization by white-rot fungi. Mycological Research Journal, vol. 106, no. 1, pp. 86-92. http://dx.doi.org/10.1017/S0953756201005202.

LIERS, C., PECYNA, M.J., KELLNER, H., WORRICH, A., ZORN, H., STEFFEN, K.T., HOFRICHTER, M. and ULLRICH, R., 2013. Substrate oxidation by dye-decolorizing peroxidases (DyPs) from wood- and litter-degrading agaricomycetes compared to other fungal and plant heme-peroxidases. Applied Microbiology and Biotechnology, vol. 97, no. 13, pp. 5839-5849. PMid:23111597. http://dx.doi.org/10.1007/s00253-012-4521-2.

LUCAS, M., MERTENS, V., CORBISIER, A.M. and VANHULLE, S., 2008. Synthetic dyes decolourisation by white-rot fungi: development of original microtitre plate method and screening. Enzyme and Microbial Technology, vol. 42, no. 2, pp. 97-106. PMid:22578858. http://dx.doi.org/10.1016/j.enzmictec.2007.07.023.

MOHAN, S.V., PRASAD, K.K., RAO, N.C. and SARMA, P.N., 2005. Acid azo dye degradation by free and immobilized horseradish peroxidase (HRP) catalyzed process. Chemosphere, vol. 58, no. 8, pp. 1097-1105. PMid:15664617. http://dx.doi. org/10.1016/j.chemosphere.2004.09.070.

MURUGESAN, K., NAM, I.H., KIM, Y.M. and CHANG, Y.S., 2007. Decolorization of reactive dyes by a thermostable laccase produced by Ganoderma lucidum in solid-state culture. Enzyme and Microbial Technology, vol. 40, no. 7, pp. 1662-1672. http:// dx.doi.org/10.1016/j.enzmictec.2006.08.028.

ÖZCAN, A., ÖZCAN, A.S., TUNALI, S., AKAR, T. and KIRAN, I., 2005. Determination of the equilibrium kinetic and thermodynamic parameters of adsorption of copper (II) ions onto seeds of Capsicum annuum. Journal of Hazardous Materials, vol. 124, no. 1-3, pp. 200-208. PMid:15990228. http://dx.doi. org/10.1016/j.jhazmat.2005.05.007.

PEDRI, Z.C., LOZANO, L.M.S., HERMANN, K.L., HELM, C.V., PERALTA, R.M. and TAVARES, L.B.B., 2015. Influence of nitrogen sources on the enzymatic activity and grown by Lentinula edodes in biomass Eucalyptus benthamii. Brazilian Journal of Biology $=$ Revista Brasileira de Biologia, vol. 75, no. 4, pp. 940947. PMid:26675911. http://dx.doi.org/10.1590/1519-6984.03214.

PELOSI, B.T., LIMA, L.K.S. and VIEIRA, M.G.A., 2014. Removal of the synthetic dye remazol brilliant blue $r$ from textile industry wastewaters by biosorption on the macrophyte Salvinia natans. Brazilian Journal of Chemical Engineering, vol. 31, no. 4, pp. 1035-1045. http://dx.doi.org/10.1590/01046632.20140314s00002568.

PISCITELLI, A., GIARDINA, P., LETTERA, V., PEZZELLA, C., SANNIA, G. and FARACO, V., 2011. Induction and transcriptional regulation of laccases in fungi. Current Genomics, vol. 12, no.
2, pp. 104-112. PMid:21966248. http://dx.doi.org/10.2174/138 920211795564331 .

RAHCHAMANI, J., MOUSAVI, H.Z. and BEHZAD, M., 2011. Adsorption of methyl violet from aqueous solution by polyacrylamide as an adsorbent: isotherm and kinetic studies. Desalination and Water Treatment, vol. 267, pp. 256-260.

RAO, M.A., SCELZA, R., ACEVEDO, F., DIEZ, M.C. and GIANFREDA, L., 2014. Enzymes as useful tools for environmental purposes. Chemosphere, vol. 107, pp. 145-162. PMid:24411841. http://dx.doi.org/10.1016/j.chemosphere.2013.12.059.

RIVERA-HOYOS, C.M., MORALES-ÁLVAREZ, E.D., POVEDACUEVAS, S.A., REYES-GUZMÁN, E.A., POUTOU-PIÑALES, R.A., REYES-MONTAÑO, E.A., PEDROZA-RODRÍGUEZ, A.M., RODRÍGUEZ-VÁZQUEZ, R. and CARDOZO-BERNAL, A.M., 2015. Computational analysis and low-scale constitutive expression of laccases synthetic genes gllcc1 from Ganoderma lucidum and poxa $1 \mathrm{~b}$ from Pleurotus ostreatus in Pichia pastoris. PLoS One, vol. 1, pp. e0116524. PMid:25611746.

SADAF, S., BHATTI, H.N. and BIBI, I., 2013. Efficient removal of disperse dye by mixed culture of Ganoderma lucidum and Coriolus versicolor. Pakistan Journal of Agricultural Sciences, vol. 50, pp. 261-266.

SARKAR, A.K., PAL, A., GHORAI, S., MANDRE, N.R. and PAL, S., 2014. Efficient removal of malachite green dye using biodegradable graft copolymer derived from amylopectin and poly (acrylic acid). Carbohydrate Polymers, vol. 111, pp. 108-115. PMid:25037335. http://dx.doi.org/10.1016/j.carbpol.2014.04.042.

SELVAKUMAR, S., MANIVASAGAN, R. and CHINNAPPAN, K., 2013. Biodegradation and decolourization of textile dye wastewater using Ganoderma lucidum. 3 Biotech, vol. 3, no. 1, pp. 71-79. PMid:28324348.

SRINIVASAN, A. and VIRARAGHAVAN, T., 2010. Decolorization of dye wastewaters by biosorbents: a review. Journal of Environmental Management, vol. 91, no. 10, pp. 1915-1929. PMid:20627542. http://dx.doi.org/10.1016/j.jenvman.2010.05.003.

WARIISHI, H., VALLI, K. and GOLD, M.H., 1992. Manganese (II) oxidation by manganese peroxidase from the basidiomycete Phanerochaete chrysosporium. The Journal of Biological Chemistry, vol. 267, no. 33, pp. 23688-23695. PMid:1429709.

YAO, J., JIA, R., ZHENG, L. and WANG, B., 2013. Rapid decolorization of azo Dyes by crude manganese peroxidase from Schizophyllum sp. F17 in solid-state fermentation. Biotechnology and Bioprocess Engineering; BBE, vol. 18, no. 5, pp. 868-877. http://dx.doi.org/10.1007/s12257-013-0357-6.

ZADRAŽIL, F. and BRUNNET, H., 1981. Investigation of physical paramenters important for the solid-state fermentation of straw by white rot fungi. European Journal of Applied Microbiology and Biotechnology, vol. 11, no. 3, pp. 183-188. http://dx.doi. org/10.1007/BF00511259.

ZHOU, Q., YANG, W., LIN, J.F. and GUO, L.Q., 2015. Optimization of medium $\mathrm{pH}$, growth media compositions and analysis of nutritional components of Ganoderma lucidum in submerged culture fermentation. European Journal of Medicinal Plants, vol. 6, no. 1, pp. 17-25. http://dx.doi.org/10.9734/EJMP/2015/14828.

ZHOU, X.W., SU, K.Q. and ZHANG, Y.M., 2012. Applied modern biotechnology for cultivation of Ganoderma and development of their products. Applied Microbiology and Biotechnology, vol. 93, no. 3, pp. 941-963. PMid:22170106. http://dx.doi.org/10.1007/ s00253-011-3780-7. 